\title{
Can bioelectrical impedance analysis effectively reflect the nutritional status of intensive care unit patients?
}

\author{
A Taggu*, B Krishna, S Sampath, SR Wudaru \\ From ESICM LIVES 2015 \\ Berlin, Germany. 3-7 October 2015
}

\begin{abstract}
Introduction
Use of Bioelectrical Impedance Analysis (BIA) to assess nutritional status in intensive care unit (ICU) patients has not been extensively studied.Traditionally used clinical and biochemical indicators are not reliable in critically ill patients [1].
\end{abstract}

\section{Objectives}

To test the hypothesis that BIA indices can reliably evaluate nutritional status in ICU patients.

\section{Methods}

A prospective observational study done in patients admitted to medical ICU between 1st October and 31st December 2014. After informed consent, all patients $>18$ years were included. Exclusion criteria were pregnancy, amputees, Body mass Index $>34$ and $<16 \mathrm{Kg} / \mathrm{m}^{2}$, those with cardiac pacemakers and ascites [2]. Baseline demographics, clinical, biochemical and BIA data were recorded. Based on serum albumin (SA) and total lymphocyte count (TLC) [3], three nutritional status groups were formed. Well-nourished group (WNG) had SA $\geq 3.5 \mathrm{~g} / \mathrm{dl}$ and TLC $\geq 1400$ cells $/ \mathrm{m}^{3}$ and severely malnourished group (SMNG) had SA $<2.8 \mathrm{~g} / \mathrm{dl}$ and TLC $<1000$ cells/ $\mathrm{mm}^{3}$. Moderately malnourished group (MMNG) had values in between the two groups.

\section{Results}

Out of the ninety patients, 66.7\% (60/90) were in MMNG and $11 \%$ in SMNG. On comparison of traditional indicators with BIA, only SA, TLC and Haemoglobin were significant. BIA indices like phase angle (PA) and Extracellular water $(\mathrm{ECW}) /$ Total body water (TBW) had higher values in WNG and SMNG respectively. PA positively correlated with SA and ECW/TBW was negatively associated with SA and mechanical ventilation days.PA among non-survivors were significantly lower than survivors.

\section{Conclusions}

BIA is a reliable tool for nutritional assessment in ICU patients. $\mathrm{ECW} / \mathrm{TBW}$ and $\mathrm{PA}$ are important indices and can be used to prognosticate critically ill patients.Further studies in a larger number of patients are needed to validate this technique.

\section{Grant Acknowledgment}

I am thankful to all the patients and the staff in Medical ICU for their support and cooperation.

Published: 1 October 2015

References

1. Jensen GL, Mirtallo J, Compher C, Dhaliwal R, Forbes A, Grijalba RF, Hardy G, Kondrup J, Labadarios D, Nyulasi I, Castillo Pineda JC, Waitzberg D, International Consensus Guideline Committee: Adult starvation and disease-related malnutrition: a proposal for etiology-based diagnosis in the clinical practice setting from the International Consensus Guideline Committee. JPEN J Parenter Enteral Nutr 2010, 34(2):156-159.

2. Kyle UG, Bosaeus I, De Lorenzo AD, Deurenberg P, Elia M, Manuel Gómez J, et al: Bioelectrical impedance analysis-part II: utilization in clinical practice. Clin Nutr 2004, 23(6):1430-1453.

3. Seltzer MH, Fletcher S, Slocum BA, Engler PE: Instant nutritional assessment in the intensive care unit. JPEN J Parenter Enteral Nutr 1981, $5(1): 70-73$

doi:10.1186/2197-425X-3-S1-A581

Cite this article as: Taggu et al:: Can bioelectrical impedance analysis effectively reflect the nutritional status of intensive care unit patients? Intensive Care Medicine Experimental 2015 3(Suppl 1):A581. 